\title{
Feasibility study of high-temperature thermoseed inductive hyperthermia in melanoma treatment
}

\author{
QI-SHENG XIA ${ }^{1}$, XUAN LIU $^{1}$, BO XU ${ }^{1}$, TIAN-DE ZHAO ${ }^{1}$, HONG-YAN LI ${ }^{1}$, ZHI-HUA CHEN $^{1}$, QING XIANG ${ }^{1}$, \\ CHUAN-YING GENG ${ }^{1}$, LIN PAN ${ }^{2}$, RUN-LEI HU ${ }^{3}$, YU-JUN QI ${ }^{4}$, GUANG-FEI SUN ${ }^{4}$ and JIN-TIAN TANG ${ }^{5}$ \\ ${ }^{1}$ Department of Biochemistry and Molecular Biology, ${ }^{2}$ Central Laboratory, Institute of Clinical Medical Sciences, \\ China-Japan Friendship Hospital, Beijing 100029; ${ }^{3}$ Department of Thoracic Surgery, Hangzhou First People's Hospital, \\ Hangzhou 310006, Zhejiang Province; ${ }^{4}$ Department of Metal Physics, Beijing University of Science and Technology, \\ Beijing 100083; ${ }^{5}$ Department of Engineering Physics, Key Laboratory of Particle and Radiation Imaging \\ (Tsinghua University), Ministry of Education Tsinghua University, Beijing 100084, P.R. China
}

Received August 23, 2010; Accepted November 17, 2010

DOI: $10.3892 /$ or.2011.1143

\begin{abstract}
Current treatment modalities for melanoma do not offer satisfactory efficacy. We have developed a new, minimally invasive hyperthermia technology based on radio-frequency hyperthermia. Herein, we investigated the feasibility of using a nickel-copper thermoseed for inductive hyperthermia at a relatively high temperature $\left(46-55^{\circ} \mathrm{C}\right)$. In vitro, the thermoseed showed good thermal effects and effective killing of B16/F10 melanoma cells. Temperatures of $53.1 \pm 0.5^{\circ} \mathrm{C}$ were achieved for a single thermoseed and $56.5 \pm 0.5^{\circ} \mathrm{C}$ for two in parallel (spacing $5 \mathrm{~mm}$ ). No B16/F10 melanoma cells survived with heating time longer than $20 \mathrm{~min}$ in the parallel thermoseed group. Magnetic fields or thermoseeds alone did not affect the survival rate of $\mathrm{B} 16 / \mathrm{F} 10$ cells $(\mathrm{P}>0.05)$. In vivo, B16/F10 melanoma cells were subcutaneously injected into the right axilla of C57BL/6 mice. After the tumors grew to $\sim 11-13 \mathrm{~mm}$, two thermoseeds (spacing $5 \mathrm{~mm}$ ) were implanted into the tumors and the mice were subjected to an alternating magnetic field $(100-250 \mathrm{kHz}, 15 \mathrm{kA} / \mathrm{m})$ to induce hyperthermia. The temperature at the center of the tumor reached $46^{\circ} \mathrm{C}$ at $5 \mathrm{~min}$ and plateaued at $50^{\circ} \mathrm{C}$. Thermoseed treatment produced large necrotic areas, inhibited tumor growth in $60 \%$ (6 of 10) of animals and prolonged survival time $(\mathrm{P}<0.05)$. Thus, with further optimization and testing, high-temperature thermoseed inductive hyperthermia may have therapeutic potential for melanoma.
\end{abstract}

\section{Introduction}

The World Health Organization reports 132,000 new cases of melanoma each year (1). Current treatment modalities

Correspondence to: Dr Jin-Tian Tang, Institute of Medical Physics and Engineering, Tsinghua University, Haidian District, Beijing 100084, P.R. China

E-mail: tangjt@mail.tsinghua.edu.cn

Key words: melanoma, thermoseed, inductive heating, hyperthermia, alternating magnetic field include surgery, chemotherapy, radiotherapy, and immunotherapy, but none of them offers satisfactory efficacy. Hyperthermia treatment is used alone or as an adjunct with radiotherapy and/or chemotherapy (2-5). Traditional hyperthermia $\left(41-43^{\circ} \mathrm{C}\right.$ or even lower) can syner-gistically enhance the therapeutic effects of radiotherapy by inducing apoptosis; whereas at higher temperatures, such as thermal ablation $\left(>60^{\circ} \mathrm{C}\right)$, direct killing occurs by necrosis $(6,7)$.

Current heating methods for local hyperthermia include radiofrequency, microwave, and ultrasound, but all have limitations (8). Herein, we describe a radiofrequency technique using thermoseed inductive hyperthermia known as magnetic mediated hyperthermia (MMH) (9-11). In one form of this treatment modality, ferromagnetic alloy rods (thermoseeds) are implanted into the tumor areas under imaging guidance and then placed into an alternating magnetic field. The thermoseeds generate heat via eddy currents and transmit the heat to the tumor tissues around them. This technique has the following advantages over other hyperthermia methods (12): 1) the implanted thermoseeds can obtain energy from an external magnetic field without wire connections; 2) thermoseeds are temperature self-controlling to restrict the maximum temperature, improve treatment safety, and decrease the need for invasive temperature measurement; 3) non-implanted tissues do not generate heat in the alternating magnetic field used to produce hyperthermia and the thermoseed temperature increases quickly, therefore the heating of normal tissues is avoided; 4) thermoseed implantation methods are similar to the placement of brachytherapy seeds but are not radioactive, thus physicians require no special protection during implantation; 5) thermoseeds with good biocompatibility can be permanently implanted, and repeated heating can be conducted after implantation if tumors recur.

Thermoseed inductive hyperthermia provides relatively precise control of tissue destruction and spares adjacent tissue (11), enabling the use of a higher temperature range than traditional hyperthermia. Although thermoseed inductive hyperthermia is primarily used for deep-seated tumors, we think it also shows good potential for the treatment of melanoma. The success of this heating technology is strongly 
dependent on the precision and control of thermal deposition, which is largely dependent on the precise implantation of the thermoseeds. As most melanomas are located on the body surface, the implantation procedure is relatively simple and precise.

Herein, we used a higher temperature range $\left(46-55^{\circ} \mathrm{C}\right)$ than normal for thermoseed hyperthermia because: 1) this temperature is sufficient to kill cells directly. Temperatures $>46^{\circ} \mathrm{C}$ can directly induce cell damage, including severe protein denaturation and DNA damage, largely these changes are irreversible and finally results in death of the cells $(8,13)$; 2 ) this temperature may reduce the common risk of shock syndrome in thermal ablation. When thermal ablation temperatures $\left(>60^{\circ} \mathrm{C}\right)$ are obtained, there is the high risk of a shock syndrome induced by the sudden large production of necrotic tumor material. However, a relative low temperature range $\left(46-55^{\circ} \mathrm{C}\right)$ can increase the proportion of apoptotic cells among the dead cells, this will reduce the risk of shock syndrome $(11)$; 3) tumor cell immunogenicity can be maintained. In cytotoxic temperature (e.g. $>46^{\circ} \mathrm{C}$ ) condition, tumor cells swell and break into pieces allowing antigen release. This creates a large antigen load for the generation of antitumor immunity. While higher temperatures $\left(>60^{\circ} \mathrm{C}\right)$ always cause severe protein denaturation, this will destroy the immunogenicity of tumor cells $(14-18) ; 4)$ the temperature range is relatively easier to obtain and safer than higher temperatures (e.g., for thermal ablation therapy). Compared with the temperature range of thermal ablation, our temperature range is relatively low. By adjusting the magnetic parameters and thermoseed array parameters, these temperatures are easy to obtain and safer. Curie effect of the thermoseeds can strictly restrict the temperature of heating area, therefore, very high temperatures, and thus tissue burning and charring are avoided (11).

We used a nickel-copper thermoseed with a Curie point of $57^{\circ} \mathrm{C}$ to test the following: 1) whether this type of thermoseed achieves the desired temperature elevation in an alternating magnetic field; 2) the hyperthermia effects induced by this kind of thermoseed on melanoma cells cultured in vitro; 3 ) the therapeutic effects of high-temperature thermoseed hyperthermia on mice with melanoma.

\section{Materials and methods}

Tumor cell line and animal model. Mouse B16/F10 melanoma cells (Shanghai Institute of Life Science, CAS, China) were maintained in Dulbecco's modified Eagle's medium (DMEM) (Gibco, USA) supplemented with 10\% FBS (Sigma, USA) and antibiotics (penicillin and gentamicin, $50 \mathrm{U} / \mathrm{ml}$ each) and grown at $37^{\circ} \mathrm{C}$ in an atmosphere containing $5 \% \mathrm{CO}_{2}$.

Male C57BL/6 mice, 8 weeks old, with body weight of $20 \pm 2 \mathrm{~g}$, were purchased from Weitong Lihua Experimental Animal Center (Beijing, China). To prepare tumor-bearing mice, $1 \times 10^{7} \mathrm{~B} 16 / \mathrm{F} 10$ cells were injected subcutaneously into the right axilla. Melanoma nodules were allowed to grow to 11-13 $\mathrm{mm}$ in diameter, and then the mice were used for experiments.

All the animal experiments were performed according to the principles described in the Guide for the Care and Use of Laboratory Animals as promulgated by the Beijing Standing Committee of PNC.
Thermoseeds and alternating magnetic field. Thermoseeds Nickel-copper alloy, Curie point: $57^{\circ} \mathrm{C}, 72 \%$ nickel and $27 \%$ cuprum; diameter, $0.9 \mathrm{~mm}$ and length, $1.04 \mathrm{~cm}$; developed in collaboration with the Department of Metal Physics, Beijing University of Science and Technology.

Alternating magnetic field type: SP-04ABC $4 \mathrm{~kW}$; frequency: $100-250 \mathrm{kHz}$; amplitude: maximum $15 \mathrm{kA} / \mathrm{m}$; heating current: 0-450 A; induction coil parameters: diameter $5 \mathrm{~cm}, 4$ turns and two-fold; provided by Shenzhen Shuangping Power Supply Technology Co., Ltd., Shenzhen, China. In every experiment, each dish or mouse was placed inside the coil such that the dish or tumor nodule was positioned at the center area of the coil, which had a relatively higher magnetic field strength and uniform magnetic distribution.

Determination of heating curves for thermoseeds. One or two thermoseeds (spacing $5 \mathrm{~mm}$ ) were fixed at the center of culture dishes containing 2.0-ml cell culture medium (no cells). A plastic foam was used for thermal insulation of the culture dishes, the dishes were placed inside the coil center with the long axis of the thermoseeds parallel to the direction of the magnetic field. The heating current was fixed at $450 \mathrm{~A}$, and thermocouples (type: IT-18 copper-constantan, diameter: $1 \mathrm{~mm}$, temperature response time: $0.1 \mathrm{sec}$, Physitemp, NJ, USA) fixed at the edge of dishes were used to monitor temperature changes via a 4-channel digital display instrument (type: XS01A-4, Beijing Kunlun Tianchen Instrument Science \& Technology Co., Ltd., Beijing, China) for data recording.

Determination of cell viability with methyl thiazolyl tetrazolium (MTT) colorimetry. Treated B16 cells were divided into 96-well microplates (200 $\mu 1 /$ well, 6 wells/group) at $10^{3}-10^{5} / \mathrm{ml}$. The microplates were centrifuged at $1,500 \mathrm{rpm}$ for $10 \mathrm{~min}$. MTT $(20 \mu 1$ at $5 \mathrm{mg} / \mathrm{ml}$; Beijing Tianlai Biomedical Technology Co., Ltd, Beijing, China) was added to each well and then incubated at $37^{\circ} \mathrm{C}$ for $4 \mathrm{~h}$. The supernatant was carefully removed and $150 \mu 1$ DMSO (Beijing Branch, Chinese Pharmaceutical Company, Beijing, China) was added to each well. OD values were measured with a microplate reader (East China Vacuum Tube Factory, Shanghai, China) after $30 \mathrm{~min}$. The detection wavelength was $570 \mathrm{~nm}$ and reference wavelength $492 \mathrm{~nm}$. The survival rate of cells was calculated as follows:

Survival rate $(\%)=(\mathrm{OD}$ experiment $-\mathrm{OD}$ blank/OD control - OD blank) x $100 \%$

Where OD blank $=$ OD value when $\mathrm{B} 16$ cell count was 0 , OD control $=\mathrm{OD}$ value of $\mathrm{B} 16$ cells measured under room temperature control conditions. OD experiment $=$ OD values of B16 cells measured under other treatment conditions. The death rate $=1$ - survival rate .

In vitro thermoseed inductive hyperthermia. When B16/F10 cells reached the exponential growth phase, cells were trypsinized (0.25\% trypsin; Gibco) and plated at $2 \times 10^{5} / \mathrm{ml}$ (35 mm x $10 \mathrm{~mm}$, Corning, USA). Cells were separated into six groups: (A) room temperature control group, (B) magnetic field control group, (C) single-thermoseed control group, (D) double-thermoseed control group, (E) single-thermoseed 


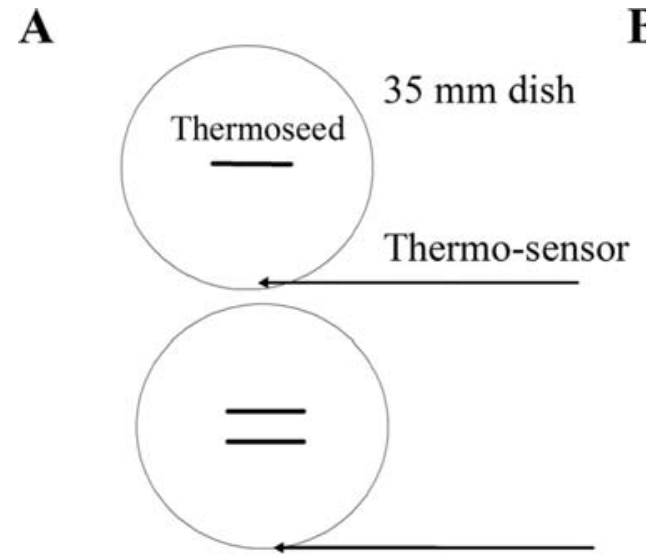

B

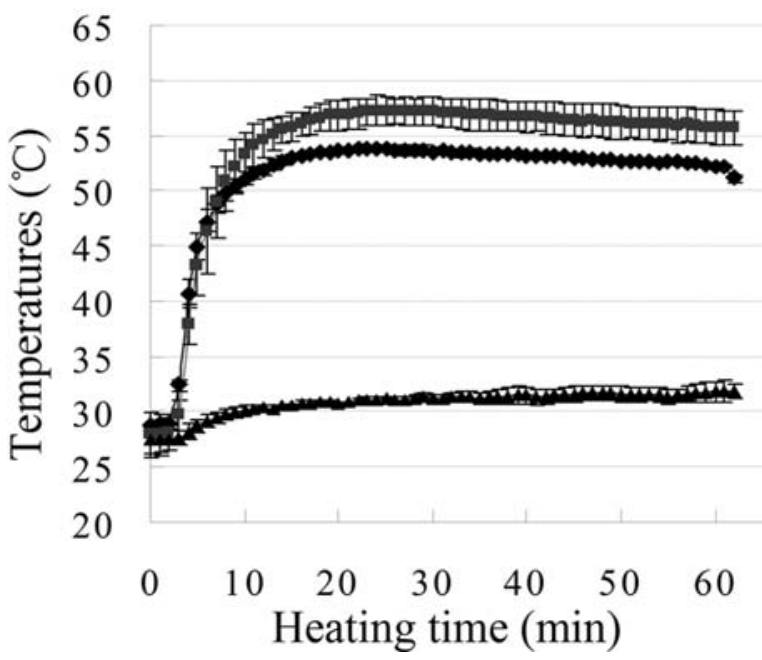

Figure 1. (A) An illustration of the placement of thermoseeds and thermo-sensor in a 35-mm dish. (B) Temperature increases of thermoseed heating in a cell

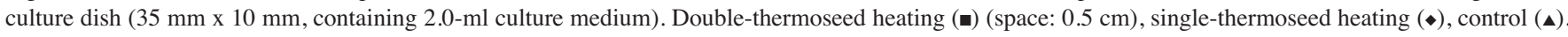
Heating began at $2 \mathrm{~min}$ and finished at $62 \mathrm{~min}$. Data points and bars are the means and SDs of three independent experiments.

hyperthermia group and $(\mathrm{F})$ double-thermoseed hyperthermia group. Then groups $\mathrm{A}, \mathrm{E}$ and $\mathrm{F}$ were divided into 6 subgroups based on heating time $(5,10,15,20,25$ and $30 \mathrm{~min})$, while the maximum heating time (30 min) was used in groups B-D. The culture medium in each culture dish was replaced with fresh culture medium before treatment to ensure that each culture dish contained $2.0 \mathrm{ml}$. The thermoseed control group and room temperature control group were maintained at room temperature. The hyperthermia group and magnetic field control group were placed into magnetic field coils with a heating current of $450 \mathrm{~A}$. Morphological observation and cell viability determinations were made immediately after heating.

Implantation of thermoseeds and in vivo thermoseed hyperthermia. Two thermoseeds were implanted in parallel at an interval of $\sim 0.5 \mathrm{~cm}$ through puncture needles (provided by Department of Radiation Oncology, China-Japan Friendship Hospital, Beijing). After implantation, an X-ray (Type KXO 15R; Toshiba, Japan) was taken to verify the position of the thermoseeds. Tumor-bearing mice were separated into two parts, part I for temperature monitoring during hyperthermia and histopathological observation, and part II for the observation of tumor volume and survival time.

Part I: Five animals. Two thermoseeds were implanted (spacing $5 \mathrm{~mm}$ ) and then placed inside the alternating magnetic field for heating. The long axis of the thermoseeds was kept parallel to the direction of magnetic field. Three temperature points were chosen for each mouse: tumor center, tumor margin, and rectum. During implantation and hyperthermia treatment, mice were anesthetized by intraperitoneal injection of sodium pentobarbital ( $60 \mathrm{mg} / \mathrm{kg}$, Sigma). The heating process lasted for $20 \mathrm{~min}$. The tumor tissues were resected after hyperthermia treatment and fixed in a $10 \%$ formalin solution for $24 \mathrm{~h}$. Serial H\&E-stained specimens were then prepared for histological examination.

Part II: Thirty-eight animals. The mice were separated into four groups. Control group (group C, 9 mice): received no treatment. Magnetic field control group (group M, 10 mice): kept in the same magnetic field for $15 \mathrm{~min}$. Thermoseed control group (group T, 9 mice): two thermoseeds were implanted into the tumors, but not put into the magnetic field. Hyperthermia group (group H, 10 mice): 15 min (including a 5 min temperature-increasing period) hyperthermia treatment after thermoseed implantation (spacing $5 \mathrm{~mm}$ ). Temperatures were not monitored during hyperthermia treatment and the heating current was fixed at $450 \mathrm{~A}$. The mice were not anesthetized except during implantation to evaluate the tolerability of the heating procedure. Tumor diameters were measured with a caliper every 2 days, and the average size determined by applying the following formula with length and width in $\mathrm{mm}$ :

$$
\text { Tumor size }=0.5 \times(\text { length }+ \text { width })
$$

Pre-treatment tumor size reflected baseline tumor size, and other data were converted into relative tumor size as follows: relative tumor size $=$ tumor size $/$ baseline tumor size .

Statistical analysis. Data are from at least three independent experiments and expressed as mean \pm SD. SPSS10.0 software was used for data processing. Analysis of variance (ANOVA) was used to analyze the differences between groups. The logrank test was used to analyze the survival curve. $\mathrm{P}<0.05$ was considered statistically significant.

\section{Results}

Temperature curve of thermoseeds in culture dishes. In order to evaluate the heating character of thermoseeds in the alternating magnetic field applied, we measured the temperature elevation of thermoseeds in vitro. Fig. 1A shows the placement of thermoseeds and thermo-sensor. The temperature plateaued $15 \mathrm{~min}$ after heating at $53.1 \pm 0.5^{\circ} \mathrm{C}$ for a single thermoseed and $56.5 \pm 0.5^{\circ} \mathrm{C}$ for two in parallel (spacing $5 \mathrm{~mm}$ ) (Fig. 1B), suggesting satisfactory temperature elevation in the alternating magnetic field. 
A

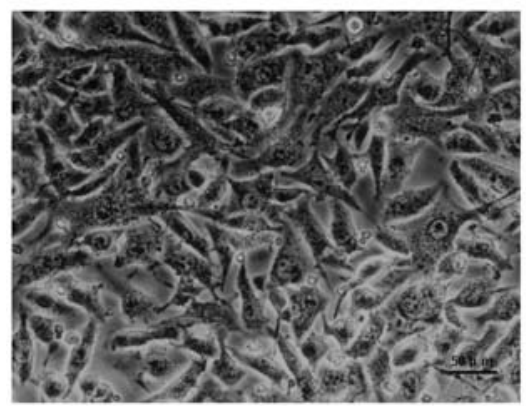

D

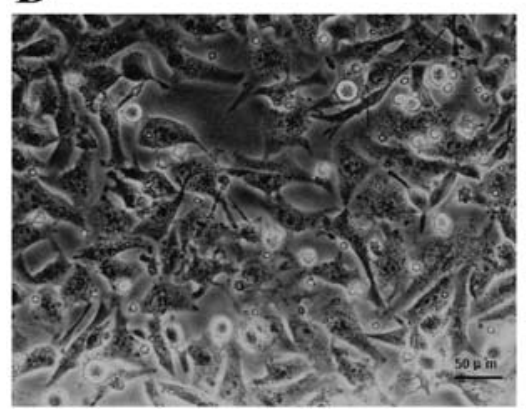

B

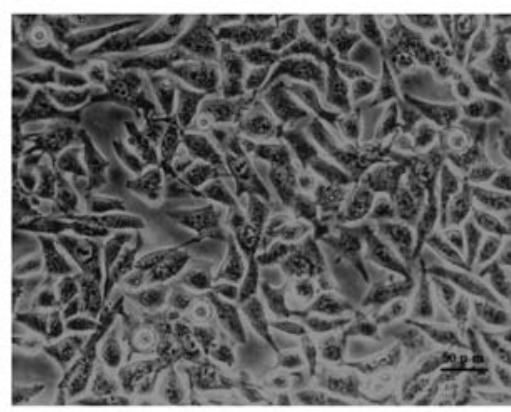

E

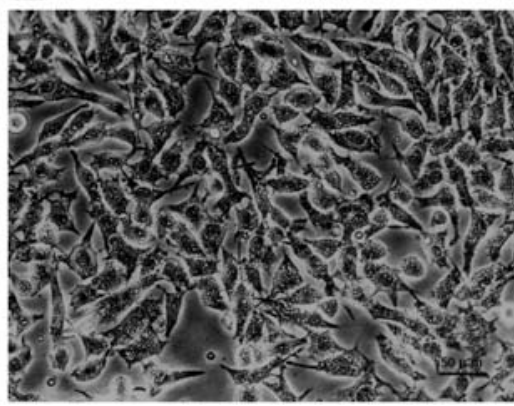

C

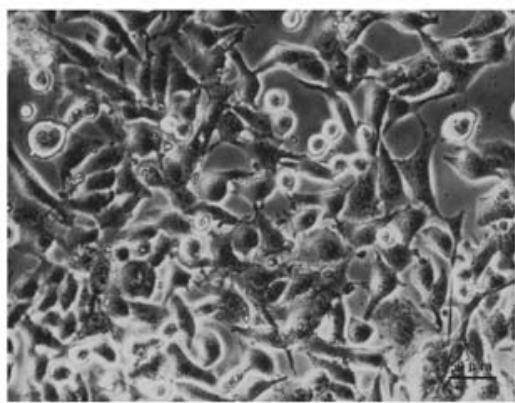

F

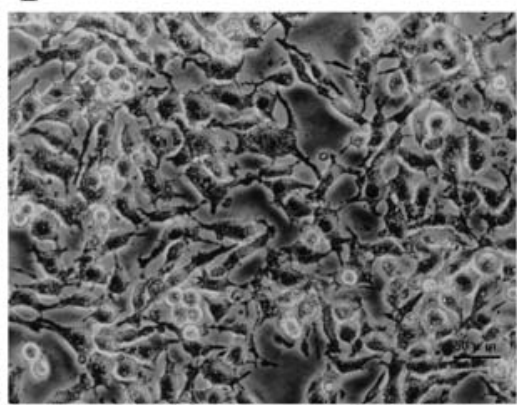

Figure 2. Morphologic effect on B16 melanoma cells. Treatment time was 30 min except F (25 min). Group A, room-temperature control; group B, magnetic control; group C, single-thermoseed control; group D, double-thermoseed control; group E, single-thermoseed heating; and group F, double-thermoseed heating. Group E showed apoptotic or necrotic morphologic changes while group F showed mostly necrotic changes. Scale bar, $50 \mu \mathrm{m}$.
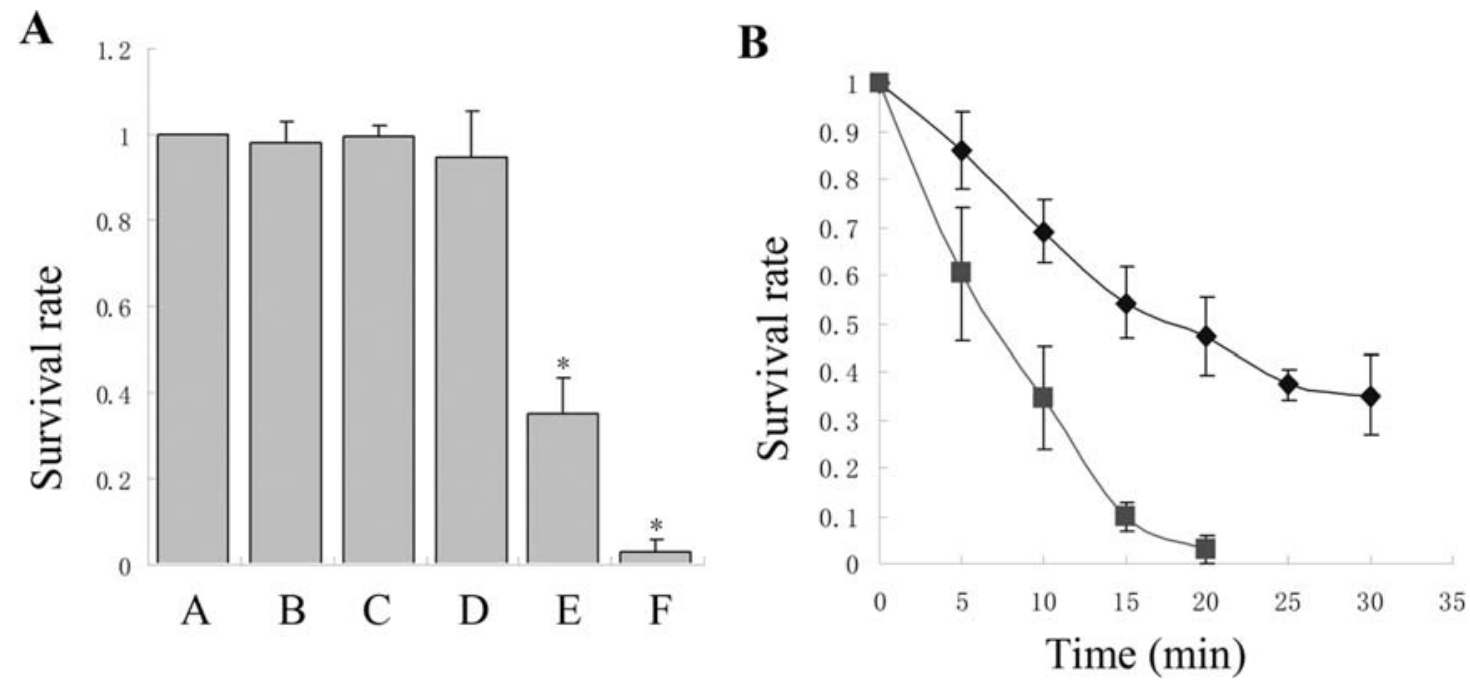

Figure 3. (A) Cell survival rates of different groups after treatment. A, room-temperature control group; B, magnetic control group; C, single-thermoseed control group; D, double-thermoseed control group; E, single-thermoseed heating group (30 min subgroup); and F, double-thermoseed heating group (20 min subgroup). (B) Survival rate of B16 cells after thermoseed inductive heating at different times. Single-thermoseed heating group (group H1) ( $\bullet$ ), doublethermoseed heating group (group H2) ( $\mathbf{a})$. $\mathrm{P}<0.05$ (compared with the four control groups). Data points and bars are the means and SDs of three independent experiments.

Morphological changes of cultured B16/F10 cells after treatment. Groups A-D showed morphology similar to normal B16/F10 cells, with regular shapes and clear nuclei (Fig. 2). However, hyperthermia (group E) decreased the cell size, produced cell-surface bubbles, and induced karyopyknosis and chromatin margination in some cells. In group F, most cells showed necrotic changes, swelled, cell membrane rupture, and the cytoplasm effused with karyorrhexis and abundant cell debris.

Viability of B16 cells after thermoseed hyperthermia. The magnetic field or thermoseeds alone did not affect cell survival rates $(\mathrm{P}>0.05)$ (Fig. 3A). Thermoseed hyperthermia decreased cell survival (Fig. 3A and B), with higher temperatures 
A

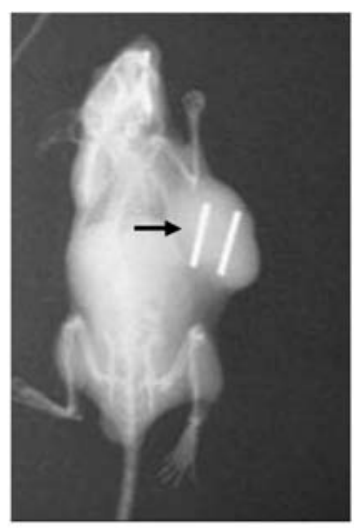

C

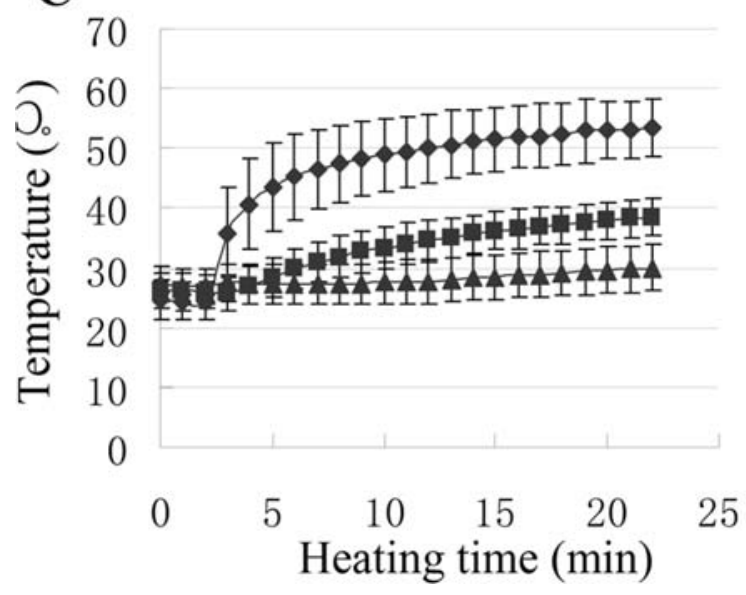

B

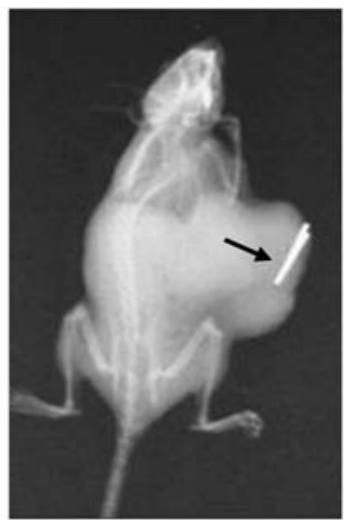

D

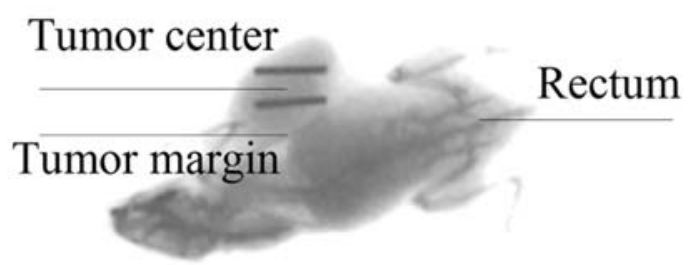

Figure 4. (A) Radiographs of mice in the hyperthermia treatment group after thermoseeds were implanted. (B) Radiographs of mice in the thermoseed control group after thermoseeds were implanted. The directions of thermoseeds (arrows) meet the desired arrangement. (C) Temperature increases in the tumor center $(\bullet)$, tumor margin ( $\mathbf{(})$, and rectum ( $\mathbf{\Delta})$ (indicates body temperature) during the heating procedure. Heating began at 2 min and finished at 22 min. Data points and bars are the means and SDs of five mice. (D) An illustration of the thermoseed placement and temperatures measure points.

inducing more death: the group E death rate was $53 \%$ and group F was $96.9 \%$ with a 20 -min heating time. Longer heating times also increased death rates, with group $\mathrm{F}$ death rates at 5,10 , and 15 min of 40,66, and $90.1 \%$, respectively. No cells survived 25 min of heating in group $\mathrm{F}$.

$X$-ray radiograph after thermoseed implantation into mouse tumors. The thermoseed rods were successfully implanted in the mice, as shown by the rod-shaped, high-density field in the tumor on the right side of the mouse (Fig. 4A and B).

Monitoring of temperatures during hyperthermia treatment. The initial body temperature before hyperthermia was $28^{\circ} \mathrm{C}$ (due to anesthesia). As shown in Fig. 4C, the temperature at the tumor center reached $46^{\circ} \mathrm{C}$ at 5 min post-heating and plateaued at $50^{\circ} \mathrm{C}$. The temperature at the tumor margin increased slowly and reached $38^{\circ} \mathrm{C}$ at the end of hyperthermia. Rectal temperatures remained $<30^{\circ} \mathrm{C}$. Fig. $4 \mathrm{D}$ showed the placement of thermoseeds and thermo-sensor in a tumorbearing mouse.

Pathological observation of tumor tissues. Unheated tumors showed ischemic necrosis in the tumor center but many surviving tumor cells around the supply vessels (Fig. 5A) that were actively proliferating (Fig. 5B). Hyperthermia-induced coagulation necrosis in the tumor tissues was around the implantation sites, including in the supply vessels area. The cavities in the figure are thermoseed implantation sites (Fig. 5C). Microscopic examination showed loss of cell structure, with karyorrhexis and cell debris. Some tumor cells showed apoptotic-like changes, such as karyopyknosis, chromatin margination, and condensation (Fig. 5D). Tumor cells around the blood vessels also showed coagulation necrosis.

Effects of thermoseed hyperthermia on tumor growth. Initially, 42 tumor-bearing mice were used in part II to observe the antitumor effect of thermoseed hyperthermia. One mouse in group $\mathrm{T}$ and another in group $\mathrm{H}$ died after thermoseed implantation. The possible reasons for the dead mice are anesthesia accidence and thermoseeds implantation-induced trauma. Two mice in group $\mathrm{H}$ were bitten by others in the same cage and died. Pre-treatment tumor sizes $(10-17 \mathrm{~mm}$ in diameter, average $11-13 \mathrm{~mm}$ ) were the same $(\mathrm{P}>0.05)$, and mice showed good tolerance for the heating procedure without anesthesia.

The tumor size in most groups increased consistently with time; however, tumor size remained initially stable in group $\mathrm{H}$ (6/10 mice), but increased one week later (Fig. 6A). The 
A

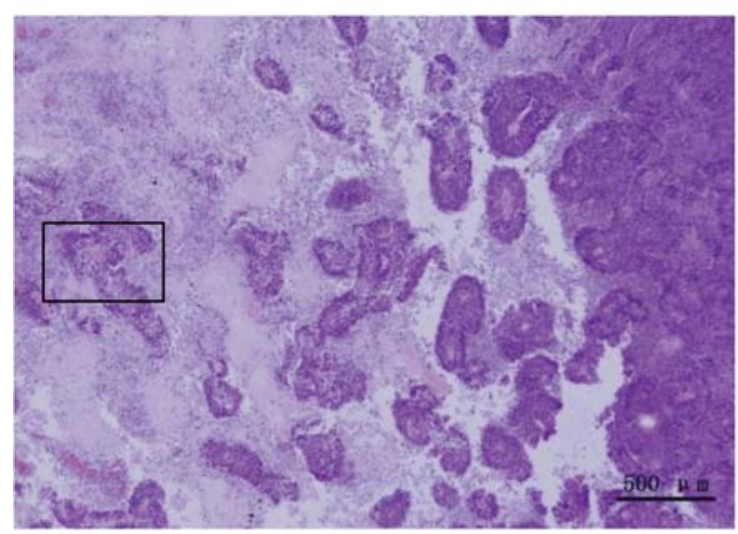

C

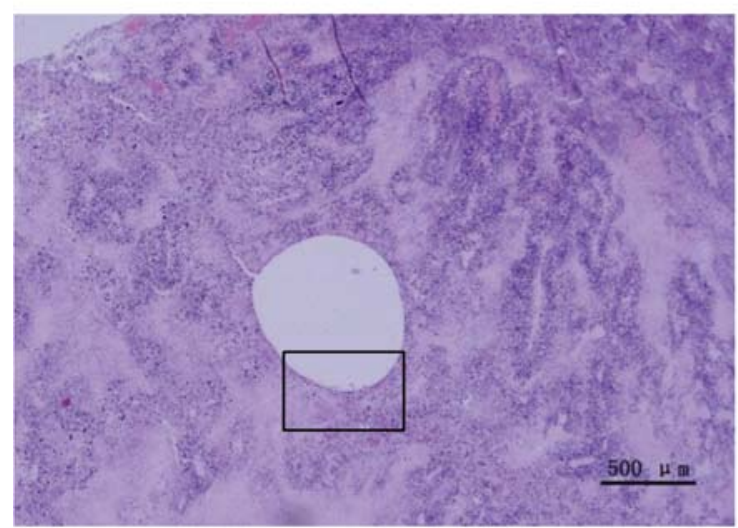

B

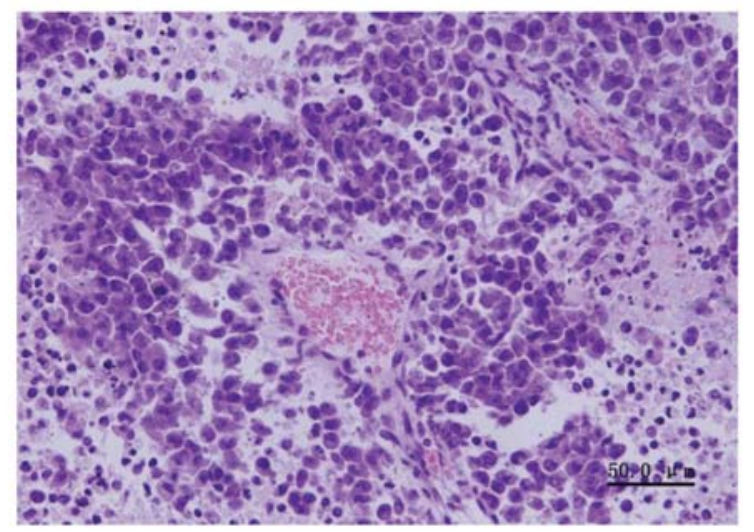

D

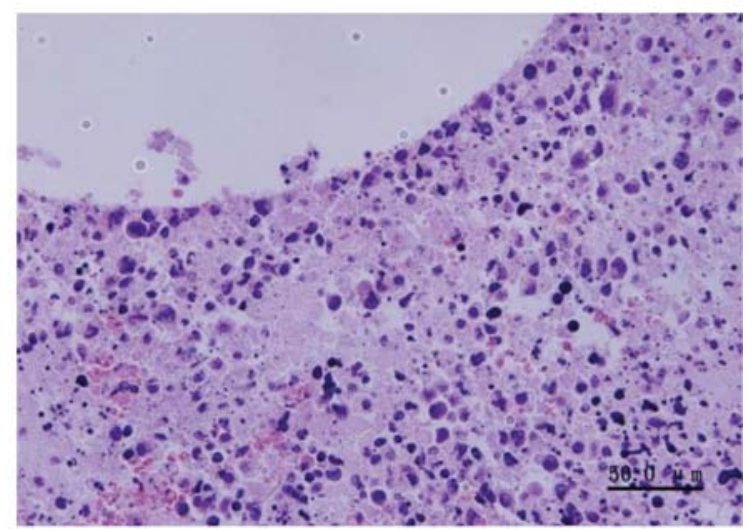

Figure 5. Histological sections of unheated (A and B) and heated (C and D) mouse tumors stained with H\&E. Samples were fixed with $10 \%$ formalin. (C) The thermoseed insertion site, (B) an amplification of the rectangular area in (A), and (D) an amplification of the rectangular area in (C). There was a large range of coagulation necrosis around the thermoseed implantation sites after hyperthermia treatment. Bar in (A and C) is $500 \mu \mathrm{m}$ and $50 \mu \mathrm{m}$ in (B and D).

A

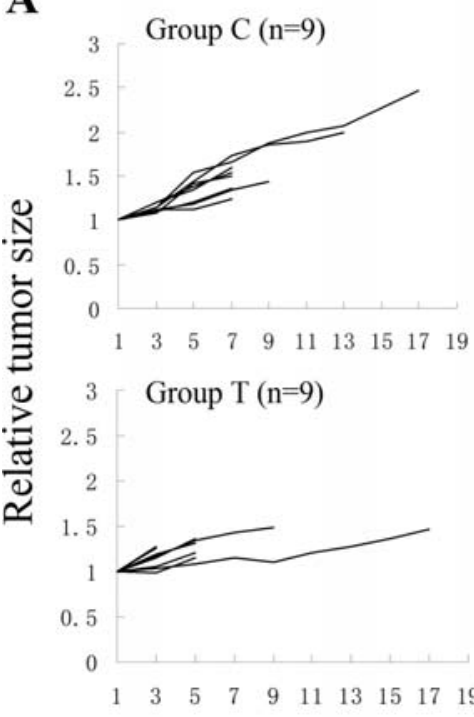

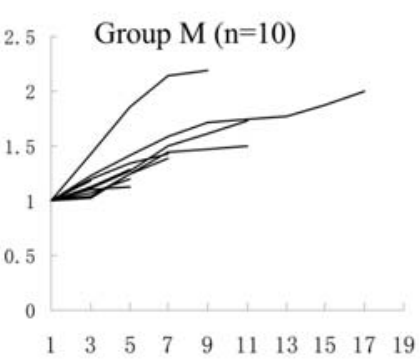

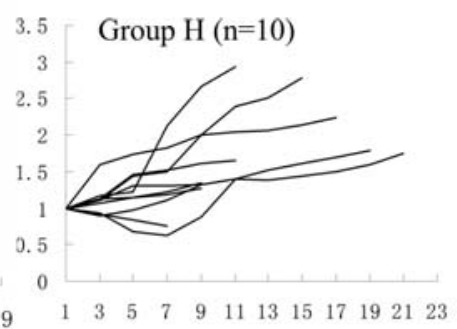

B

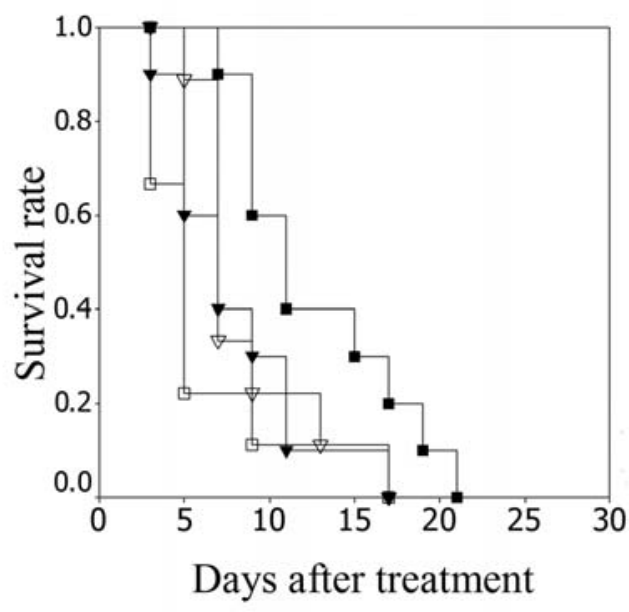

\section{Days after treatment}

Figure 6. (A) Time course of post-treatment tumor growth in each group. Each line represents tumor growth in a single mouse; end of the line indicates when each mouse died. Most mice (6/10) after hyperthermia had transiently inhibited tumor growth. (B) Kaplan-Meier survival rates of the tumor-bearing mice after treatment for: control group $(n=9)(\nabla)$, magnetic control group $(n=10)(\nabla)$, thermoseed control group (n=9) ( $\square$ ), and hyperthermia treatment group $(\mathrm{n}=10)(\mathbf{\square})$. 
survival rate in the three control groups was slightly lower than the hyperthermia group (Fig. 6B), with the lowest in group $\mathrm{T}$. Survival rates were the same in the three control groups $(\mathrm{P}>0.05)$, but group $\mathrm{H}$ and $\mathrm{C}(\mathrm{P}=0.0136)$ and group $\mathrm{H}$ and $\mathrm{T}$ were different $(\mathrm{P}=0.0025)$, and group $\mathrm{H}$ and $\mathrm{M}$ were not $(\mathrm{P}=0.0635)$. Mice in the hyperthermia group, like other groups, died from tumor recurrence. Some of the mice in group $\mathrm{H}$ had the fastest tumor growth rates amongst all animals, including those in the control groups. There are some possible reasons, the first, hyperthermia-induced tumor damage may cause edema in the tumor area to a certain extent and this will lead to a size increase of the tumor; the second, the wound induced by the implant of thermoseeds can also cause tissue edema; the third, thermoseed implantation and hyperthermia may stimulate the growth of the remaining tumor cells.

\section{Discussion}

Research on thermoseed inductive hyperthermia has more than 30 years of history. Basic research mainly focused on heat generation by different materials (19-33), thermoseed processing methods $(34,35)$, heating coil designs $(36,37)$, improving uniform temperature distribution (38-47), and the in vivo effects on animals $(12,21,25,28,30,32,33,36,38,41,48-51)$. Clinical research mainly focused on intracranial tumors $(52,53)$, prostate cancer $(54-56,57)$, and some other tumors $(58,59)$.

Most studies used temperatures for traditional hyperthermia $\left(<43^{\circ} \mathrm{C}\right)$ or thermal ablation $\left(>70^{\circ} \mathrm{C}\right)$. High temperature hyperthermia $\left(46-55^{\circ} \mathrm{C}\right)$ is always used in thermoseed inductive hyperthermia (26), but very few researchers investigated the feasibility of high-temperature thermoseed inductive hyperthermia in melanoma treatment. Steeves et al $(60,61)$ studied the use of thermoseed inductive hyperthermia combined simultaneously with iridium seed implants for treating ocular melanoma in a rabbit model. In this experiment, temperatures of $43.6^{\circ} \mathrm{C}$ across the tumor area were achieved, and the researchers found thermoseeds could be used to deliver biologically effective hyperthermia concurrently with radiation, but the tumor response rate of hyperthermia alone was low.

In a subsequent study, Murray et al (62) increased the heating temperature. In normal rabbit eyes, thermoseed heating to $48^{\circ} \mathrm{C}$ or $54^{\circ} \mathrm{C}$ had restricted thermal effects and did not show diffuse ocular toxicity, indicating potential application in the treatment of ocular melanoma. Geng et al (50) used thermoseeds with similar characters to our study $(\mathrm{Ni}-\mathrm{Cu}$ alloy; Curie point $57^{\circ} \mathrm{C}$ ) to evaluate the effect of thermoseed inductive hyperthermia in the treatment of hepatic tumor in a mouse model. Their results showed temperature at the central area of the tumor could be heated up to $50^{\circ} \mathrm{C}$ and survival period of the mice was significantly prolonged.

Tohnai et al (59) performed a clinical trial on oral cancer by using the thermoseed with an even higher Curie point $\left(68^{\circ} \mathrm{C}\right)$. The patients were treated combined with chemotherapy. Average temperatures of the implant in the tumor reached $60.1^{\circ} \mathrm{C}$ and an $87.5 \%$ (7/8) clinical complete response was observed, indicating a promising application potential of thermoseed inductive hyperthermia in superficial cancer treatment. The character of Curie point phenomenon of ferromagnetic thermoseeds provides them an ability to restrict the maximum temperature in the heating area, this will increase the safety level during hyperthermia treatment. Another advantage of the thermoseeds applied is when thermoseed migration occurred, single low Curie thermoseedproduced heat is limited (unpublished data), and this will significantly reduce the risk of heating normal and vital tissue. Herein, we combined the advantages of our temperature range with thermoseed hyperthermia technology in melanoma treatment.

In order to find the optimal parameters for thermoseed inductive hyperthermia, we investigated the influence of thermoseed parameters and magnetic field parameters on heat productions of the thermoseed before the in vitro and in vivo experiments were performed. An obvious Curie point phenomenon could be observed when the thermoseed was heated in the alternating magnetic field applied as compared with iron rod (unpublished data). Align direction of the thermoseed in the magnetic field, length of the thermoseed and heating current of the magnetic field had an apparent affect on heat production of the thermoseed (unpublished data). Based on these results, the parameters used in the subsequent experiments were: length of the thermoseed, $1.04 \mathrm{~cm}$; heating current of the alternating magnetic field, $450 \mathrm{~A}$ (corresponding to a magnetic strength of $15 \mathrm{kA} / \mathrm{m}$ ); align direction of the thermoseed in the magnetic field, parallel to the direction of magnetic field $\left(0^{\circ}\right)$.

Cellular responses to hyperthermia $\left(40-46^{\circ} \mathrm{C}\right)$ have been clarified to some extent (13). However, cellular studies of thermoseed inductive hyperthermia at $46-55^{\circ} \mathrm{C}$ are relatively rare. Lee et al (63) showed that glass ceramic thermoseeds could kill KB cells (human oral epithelial cells) near the thermoseeds, but not far from an alternating magnetic field. We also found that thermoseed inductive hyperthermia could kill B16 melanoma cells at a rate that depended on the number of thermoseeds in the culture. The alternating magnetic field or thermoseeds alone did not influence cell morphology or survival, at least up to the last time point measured (30 min). Nickel-copper is a toxic alloy (64), but we used it for a proofof-concept approach because of its ease of handling and low cost. We are currently exploring gold plating to reduce toxicity. Other cobalt-palladium thermoseeds $(8,54-57,65)$ have suitable technical properties but are much more expensive.

Saito et al (33) studied a low Curie temperature $\left(43^{\circ} \mathrm{C}\right)$ ferromagnetic material (diameter $100 \mu \mathrm{m}$ ) in the application of melanoma treatment in a mouse model. In this study, tumorbearing mice were treated $30 \mathrm{~min}$ single or twice. Their results showed repeated heating (twice) significantly inhibited tumor growth and prolonged the survival period, while single heating could not.

However, in our study, due to a relatively higher temperature range used, the heating time for thermoseed inductive hyperthermia in C57BL/6 mice could not exceed $15 \mathrm{~min}$ (including a temperature increasing period of $5 \mathrm{~min}$ and a hyperthermia period of $10 \mathrm{~min}$ ), a repeated heating was also not permitted; otherwise, the mice would die within 1-2 days. In our opinion, there are three reasons: the first, long time heating induce more normal tissue damage; the second, more probability of shock syndrome occur during a long heating 
period; the third, the mice cannot bear the heating procedure without anesthesia for a longer time period. Another reason is thermoseeds implantation requires tumors with a diameter $>1 \mathrm{~cm}$, which is large for a mouse. We therefore used $10 \mathrm{~min}$ of hyperthermia treatment (total heating time $15 \mathrm{~min}$ ). Temperature distribution data in agar phantom, isolated pig liver and normal rabbit muscle tissue indicated that two thermoseeds spaced $0.5 \mathrm{~cm}$ apart would heat tumors with diameters of $1 \mathrm{~cm}$ (unpublished data).

The temperature in the tumor center increased to $50^{\circ} \mathrm{C}$ during treatment, this would obtain a thermal dosage of 1280 min CEM $43^{\circ} \mathrm{C}(66,67)$. However, similar to the results of Saito et al (33), our study showed single hyperthermia treatment in mice only transiently blocked tumor growth in most mice (6/10). There are three possible reasons; the first, due to the small size of tumor in mice, only 2 thermoseeds can be implanted, thus tumor edge cannot reach the desired temperature range; the second, due to the tolerance limitation, thermal dose cannot reach the requisition; the third, also due to the tolerance, repeated hyperthermia treatment cannot be performed. The treatment of multiple lobe/odd shaped melanoma tumors is a huge challenge in thermoseed inductive hyperthermia. The edge of these types of tumors are difficult to heat, this is also the reason of a poor tumor inhibition rate achieved in our study. Implanting more thermoseeds may be a method, but increasing normal tissue damage is a problem. Other treatment modalities such as radiotherapy and chemotherapy, can be used in conjunction. Further study on this aspect is needed.

Even though many challenges remain, we still think that this heating technology has potential and is applicable to the treatment of melanoma. Further comprehensive studies such as big animal experiments, are needed. Small animal experiments have some inherent limitations for testing, such as tumor volume, number of implanted thermoseeds and thermal probe, particularly treatment tolerance. Most of these difficulties can be addressed in larger animals or clinical trials. The long-term goal is to make most of the tumor area reach the desired temperature range $\left(\geq 46^{\circ} \mathrm{C}\right.$ for T90) and to last for $\geq 30 \mathrm{~min}$, to obtain a thermal dosage more than 240 CEM $43^{\circ} \mathrm{C}$ T90 $(66,67)$. Our newly developed technology (40 kHz, 0-20 kA/m, $30 \mathrm{~kW}$ ) can be used for big animal experiments and clinical trials, and hope to advance the study of thermoseed inductive hyperthermia in melanoma treatment by using this technology.

The difference in the hyperthermia group and the magnetic field control group is not significance $(\mathrm{P}=0.0635)$, probably due to the small number of animals used in the experiment. Further work is needed to confirm the role of magnetic field alone. Hyperthermia treatment can kill cells directly through heat, but also kill tumor cells in metastatic lesions through the anti-tumor immunity induced by hyperthermia (14-18), also known as the abscopal effect $(68,69)$. Eliminating metastatic tumors would be a significant advantage for the treatment of melanoma. Further work is required to confirm that the high-temperature hyperthermia $\left(46-55^{\circ} \mathrm{C}\right)$ used here induces an abscopal effect.

In conclusion, high-temperature thermoseed hyperthermia was able to damage or kill B16/F10 melanoma cells in vitro. It produced enough temperature elevation in agar phantom, isolated pig liver and normal rabbit muscle tissue, as well as in mouse tumors, created well-restricted areas of necrosis, transiently inhibited tumor growth, and prolonged the survival of melanoma-bearing mice. Further optimization of thermoseeds and alternating magnetic field parameters will allow testing of big animal models. This mini-invasive hyperthermia therapy appears promising for the treatment of melanoma.

\section{Acknowledgements}

This study was supported by a National Nature Science Foundation of China (Grant numbers: 10775085 and 30571779), Science Committee Fund of Beijing (Grant number: Z07000200540704), and Yuyuan Fund of Tsinghua University (Grant number: 20240000519).

\section{References}

1. Gray-Schopfer V, Wellbrock C and Marais R: Melanoma biology and new targeted therapy. Nature 445: 851-857, 2007.

2. Wust P, Hildebrandt B, Sreenivasa G, Rau B, Gellermann J, Riess H, Felix R and Schlag PM: Hyperthermia in combined treatment of cancer. Lancet Oncol 3: 487-497, 2002.

3. Falk MH and Issels RD: Hyperthermia in oncology. Int J Hyperthermia 17: 1-18, 2001.

4. Ross MI: Current status of hyperthermic limb perfusion for intransit melanoma. Int J Hyperthermia 24: 205-217, 2008.

5. Pennacchioli E, Fiore M and Gronchi A: Hyperthermia as an adjunctive treatment for soft-tissue sarcoma. Expert Rev Anticancer Ther 9: 199-210, 2009.

6. Harmon BV, Takano YS, Winterford CM and Gobe GC: The role of apoptosis in the response of cells and tumours to mild hyperthermia. Int J Radiat Biol 59: 489-501, 1991.

7. Horsman MR: Tissue physiology and the response to heat. Int $\mathbf{J}$ Hyperthermia 22: 197-203, 2006.

8. Diederich CJ: Thermal ablation and high-temperature thermal therapy: overview of technology and clinical implementation. Int J Hyperthermia 21: 745-753, 2005.

9. Milligan AJ and Dobelbower RR Jr: Interstitial hyperthermia. Med Instrum 18: 175-180, 1984

10. Brezovich IA and Meredith RF: Practical aspects of ferromagnetic thermoseed hyperthermia. Radiol Clin North Am 27: 589-602, 1989.

11. Moroz P, Jones SK and Gray BN: Magnetic mediated hyperthermia: current status and future directions. Int J Hyperthermia 18: 267-284, 2002.

12. Rehman J, Landman J, Tucker RD, Bostwick DG, Sundaram CP and Clayman RV: Ferromagnetic self-regulating reheatable thermal rod implants for in situ tissue ablation. J Endourol 16: 523-531, 2002.

13. Roti Roti JL: Cellular responses to hyperthermia (40-46 degrees C): cell killing and molecular events. Int J Hyperthermia 24: 3-15, 2008.

14. den Brok MH, Sutmuller RP, van der Voort R, Bennink EJ, Figdor CG, Ruers TJ and Adema GJ: In situ tumor ablation creates an antigen source for the generation of antitumor immunity. Cancer Res 64: 4024-4029, 2004.

15. Baronzio G, Gramaglia A and Fiorentini G: Hyperthermia and immunity. A brief overview. In Vivo 20: 689-695, 2006.

16. Zerbini A, Pilli M, Penna A, Pelosi G, Schianchi C, Molinari A, Schivazappa S, Zibera C, Fagnoni FF, Ferrari C and Missale G: Radiofrequency thermal ablation of hepatocellular carcinoma liver nodules can activate and enhance tumor-specific T-cell responses. Cancer Res 66: 1139-1146, 2006.

17. Mukhopadhaya A, Mendecki J, Dong X, Liu L, Kalnicki S, Garg M, Alfieri A and Guha C: Localized hyperthermia combined with intratumoral dendritic cells induces systemic antitumor immunity. Cancer Res 67: 7798-7806, 2007.

18. Zhang HG, Mehta K, Cohen P and Guha C: Hyperthermia on immune regulation: a temperature's story. Cancer Lett 271: 191-204, 2008.

19. Lilly MB, Brezovich IA and Atkinson WJ: Hyperthermia induction with thermally self-regulated ferromagnetic implants. Radiology 154: 243-244, 1985. 
20. Chen JS, Poirier DR, Damento MA, Demer LJ, Biancaniello F and Cetas TC: Development of Ni-4 wt.\% Si thermoseeds for hyperthermia cancer treatment. J Biomed Mater Res 22: 303-319, 1988.

21. Meredith RF, Brezovich IA, Weppelmann B, Henderson RA, Brawner WR Jr, Kwapien RP, Bartolucci AA and Salter MM: Ferromagnetic thermoseeds: suitable for an afterloading interstitial implant. Int J Radiat Oncol Biol Phys 17: 1341-1346, 1989.

22. Meijer JG, van Wieringen N, Koedooder C, Nieuwenhuys GJ and van Dijk JD: The development of PdNi thermoseeds for interstitial hyperthermia. Med Phys 22: 101-104, 1995.

23. van Wieringen N, van Dijk JD, Nieuwenhuys GJ, Snel CE and Cetas TC: Power absorption and temperature control of multifilament palladium-nickel thermoseeds for interstitial hyperthermia. Phys Med Biol 41: 2367-2380, 1996.

24. Paulus JA, Richardson JS, Tucker RD and Park JB: Evaluation of inductively heated ferromagnetic alloy implants for therapeutic interstitial hyperthermia. IEEE Trans Biomed Eng 43: 406-413, 1996.

25. van Wieringen $\mathbf{N}$, van Dijk JD, van Veldhuizen $J$ and Nieuwenhuys GJ: The effect of catheters and coatings on the performance of palladium-nickel thermoseeds: evaluation and design of implantation techniques. Int J Hyperthermia 13: 187-204, 1997

26. Cetas TC, Gross EJ and Contractor Y: A ferrite core/metallic sheath thermoseed for interstitial thermal therapies. IEEE Trans Biomed Eng 45: 68-77, 1998

27. Buckley PR, McKinley GH, Wilson TS, Small W, Benett WJ, Bearinger JP, McElfresh MW and Maitland DJ: Inductively heated shape memory polymer for the magnetic actuation of medical devices. IEEE Trans Biomed Eng 53: 2075-2083, 2006.

28. Ruiz-Hernández E, Serrano MC, Arcos D and Vallet-Regí M: Glass-glass ceramic thermoseeds for hyperthermic treatment of bone tumors. J Biomed Mater Res A 79: 533-543, 2006.

29. El-Sayed AH, Aly AA, EI-Sayed NI, Mekawy MM and EIGendy AA: Calculation of heating power generated from ferromagnetic thermal seed (PdCo-PdNi-CuNi) alloys used as interstitial hyperthermia implants. J Mater Sci Mater Med 18 : 523-528, 2007

30. Serrano MC, Portolés MT, Pagani R, de Guinoa JS, RuizHernández E, Arcos D and Vallet-Regí M: In vitro positive biocompatibility evaluation of glass-glass ceramic thermoseeds for hyperthermic treatment of bone tumors. Tissue Eng Part A 14: 617-627, 2008

31. Sato K, Watanabe Y, Horiuchi A, Yukumi S, Doi T, Yoshida M, Yamamoto Y, Maehara T, Naohara T and Kawachi K: Novel tumor-ablation device for liver tumors utilizing heat energy generated under an alternating magnetic field. J Gastroenterol Hepatol 23: 1105-1111,2008.

32. Sato K, Watanabe Y, Horiuchi A, Yukumi S, Doi T, Yoshida M, Yamamoto Y, Tsunooka N and Kawachi K: Feasibility of new heating method of hepatic parenchyma using a sintered $\mathrm{MgFe}_{2} \mathrm{O}_{4}$ needle under an alternating magnetic field. J Surg Res 146: $110-106,2008$

33. Saito H, Mitobe K, Ito A, Sugawara Y, Maruyama K, Minamiya Y, Motoyama S, Yoshimura N and Ogawa J: Self-regulating hyperthermia induced using thermosensitive ferromagnetic material with a low Curie temperature. Cancer Sci 99: 805-809, 2008

34. Lee YK, Kim KN, Choi SY and Kim CS: Effect of iron state on crystallization and dissolution in $\mathrm{Fe}_{2} \mathrm{O}_{3}-\mathrm{CaO}-\mathrm{SiO}_{2}$ glasses. Mater Sci Mater Med 11: 511-515, 2000.

35. Le UT, Tucker RD and Park JB: The effects of localized cold work on the heating characteristics of thermal therapy implants. J Biomed Mater Res 63: 24-30, 2002.

36. Stauffer PR, Cetas TC, Fletcher AM, DeYoung DW, Dewhirst MW, Oleson JR and Roemer RB: Observations on the use of ferromagnetic implants for inducing hyperthermia. IEEE Trans Biomed Eng 31: 76-90, 1984.

37. Stauffer PR, Sneed PK, Hashemi H and Phillips TL: Practical induction heating coil designs for clinical hyperthermia with ferromagnetic implants. IEEE Trans Biomed Eng 41: 17-28, 1994.

38. Brezovich IA, Atkinson WJ and Chakraborty DP: Temperature distributions in tumor models heated by self-regulating nickelcopper alloy thermoseeds. Med Phys 11: 145-152, 1984.

39. Chin RB and Stauffer PR: Treatment planning for ferromagnetic seed heating. Int J Radiat Oncol Biol Phys 21: 431-439, 1991

40. Chen ZP, Roemer RB and Cetas TC: Three-dimensional simulations of ferromagnetic implant hyperthermia. Med Phys 19. 989-997, 1992
41. Tompkins DT, Partington BP, Steeves RA, Bartholow SD and Paliwal BR: Effect of implant variables on temperatures achieved during ferromagnetic hyperthermia. Int J Hyperthermia 8: 241-251, 1992

42. van Wieringen N, Kotte AN, van Leeuwen GM, Lagendijk JJ, van Dijk JD and Nieuwenhuys GJ: Dose uniformity of ferromagnetic seed implants in tissue with discrete vasculature: a numerical study on the impact of seed characteristics and implantation techniques. Phys Med Biol 43: 121-138, 1998.

43. Kotte AN, van Wieringen N and Lagendijk JJ: Modelling tissue heating with ferromagnetic seeds. Phys Med Biol 43: 105-120, 1998.

44. Berthusen AH, Tucker RD and Park JB: A field-focusing device to increase power output of ThermoRod trade mark implants for thermal ablation of tissue. J Biomed Mater Res 63: 650-656, 2002.

45. Case JA, Tucker RD and Park JB: Defining the heating characteristics of ferromagnetic implants using calorimetry. J Biomed Mater Res 53: 791-798, 2000.

46. Dughiero F and Corazza S: Numerical simulation of thermal disposition with induction heating used for oncological hyperthermic treatment. Med Biol Eng Comput 43: 40-46, 2005.

47. Abe K, Shiozawa N and Makikawa M: Hyperthermia system with thermoseed set in abdominal cavity and AC-magneticfield. Conf Proc IEEE Eng Med Biol Soc 2007: 1483-1486, 2007.

48. Stauffer PR, Cetas TC and Jones RC: Magnetic induction heating of ferromagnetic implants for inducing localized hyperthermia in deep-seated tumors. IEEE Trans Biomed Eng 31: 235-251, 1984.

49. Brezovich IA, Atkinson WJ and Lilly MB: Local hyperthermia with interstitial techniques. Cancer Res 44 (Suppl 10): 4752-4756, 1984.

50. Geng YC, Wang XX, Ma Y, Hu Y and Zhang RL: Orientated thermotherapy of ferromagnetic thermoseed in hepatic tumors. World J Gastroenterol 4: 326-328, 1998.

51. Park BH, Koo BS, Kim YK and Kim MK: The induction of hyperthermia in rabbit liver by means of duplex stainless steel thermoseeds. Korean J Radiol 3: 98-104, 2002.

52. Kobayashi T, Kida Y, Tanaka T, Hattori K, Matsui M and Amemiya $\mathrm{Y}$ : Interstitial hyperthermia of malignant brain tumors by implant heating system: clinical experience. J Neurooncol 10: 153-163, 1991

53. Stea B, Rossman K, Kittelson J, Shetter A, Hamilton A and Cassady JR: Interstitial irradiation versus interstitial thermoradiotherapy for supratentorial malignant gliomas: a comparative survival analysis. Int J Radiat Oncol Biol Phys 30: 591-600, 1994.

54. Tucker RD, Platz CE, Huidobro C and Larson T: Interstitial thermal therapy in patients with localized prostate cancer: histologic analysis. Urology 60: 166-169, 2002.

55. Deger S, Boehmer D, Turk I, Roigas J, Budach V and Loening SA: Interstitial hyperthermia using self-regulating thermoseeds combined with conformal radiation therapy. Eur Urol 42: 147-153, 2002

56. Master VA, Shinohara K and Carroll PR: Ferromagnetic thermal ablation of locally recurrent prostate cancer: prostate specific antigen results and immediate/intermediate morbidities. J Urol 172: 2197-2202, 2004

57. Deger S, Taymoorian K, Boehmer D, Schink T, Roigas J, Wille AH, Budach V, Wernecke KD and Loening SA: Thermoradiotherapy using interstitial self-regulating thermoseeds: an intermediate analysis of a phase II trial. Eur Urol 45: 574-580, 2004.

58. Mack CF, Stea B, Kittelson JM, Shimm DS, Sneed PK, Phillips TL, Swift PS, Luk K, Vora N and Stauffer PR: Interstitial thermoradiotherapy with ferromagnetic implants for locally advanced and recurrent neoplasms. Int $\mathrm{J}$ Radiat Oncol Biol Phys 27: 109-115, 1993.

59. Tohnai I, Goto Y, Hayashi Y, Ueda M, Kobayashi T and Matsui M: Preoperative thermochemotherapy of oral cancer using magnetic induction hyperthermia (Implant Heating System: IHS). Int J Hyperthermia 12: 37-47, 1996.

60. Steeves RA, Murray TG, Moros EG, Boldt HC, Mieler WF and Paliwal BR: Concurrent ferromagnetic hyperthermia and 125I brachytherapy in a rabbit choroidal melanoma model. Int J Hyperthermia 8: 443-449, 1992.

61. Steeves RA, Tompkins DT, Nash RN, Blair JR, Gentry LL, Paliwal BR, Murray TG and Mieler WF: Thermoradiotherapy of intraocular tumors in an animal model: concurrent vs. sequential brachytherapy and ferromagnetic hyperthermia. Int J Radiat Oncol Biol Phys 33: 659-662, 1995. 
62. Murray TG, Steeves RA, Gentry L, Bresnick G, Boldt HC, Mieler WF and Tompkins D: Ferromagnetic hyperthermia: functional and histopathologic effects on normal rabbit ocular tissue. Int J Hyperthermia 13: 423-436, 1997.

63. Lee YK, Lee SB, Kim YU, Kim KN, Choi SY, Lee KH, Shim IB and Kim CS: Effect of ferrite thermoseeds on destruction of carcinoma cells under alternating magnetic field. J Mater Sci 38: 4221-4233, 2003.

64. Paulus JA, Parida GR, Tucker RD and Park JB: Corrosion analysis of $\mathrm{NiCu}$ and $\mathrm{PdCo}$ thermal seed alloys used as interstitial hyperthermia implants. Biomaterials 18: 1609-1614, 1997.

65. Tucker RD: Use of interstitial temperature self-regulating thermal rods in the treatment of prostate cancer. J Endourol 17: 601-607, 2003.

66. Dewhirst MW, Viglianti BL, Lora-Michiels M, Hanson M and Hoopes PJ: Basic principles of thermal dosimetry and thermal thresholds for tissue damage from hyperthermia. Int $\mathrm{J}$ Hyperthermia 19: 267-294, 2003.
67. Dewey WC: Arrhenius relationships from the molecule and cell to the clinic. Int J Hyperthermia 25: 3-20, 2009.

68. Kawai N, Ito A, Nakahara Y, Futakuchi M, Shirai T, Honda H, Kobayashi $\mathrm{T}$ and Kohri K: Anticancer effect of hyperthermia on prostate cancer mediated by magnetite cationic liposomes and immune-response induction in transplanted syngeneic rats. Prostate 64: 373-381, 2005.

69. Ito A, Honda H and Kobayashi T: Cancer immunotherapy based on intracellular hyperthermia using magnetite nanoparticles: a novel concept of 'heat-controlled necrosis' with heat shock protein expression. Cancer Immunol Immunother 55: 320-328, 2006. 